Удк: 616.127-005.8

\title{
Modern aspects of myocardial infarction treatment in older patients
}

\author{
๑2020. K.L. Kozlov' ${ }^{1,2}$, A.N. Bogomolov²*, N.G. Lukianov ${ }^{1}$, E.I. Senkina ${ }^{2}$, A.E. Pukhalskaya ${ }^{2}$ \\ ${ }^{1}$ Military Medical Academy, Saint Petersburg, Russia \\ ${ }^{2}$ Saint Petersburg Institute of Bioregulation and Gerontology, Saint Petersburg, Russia

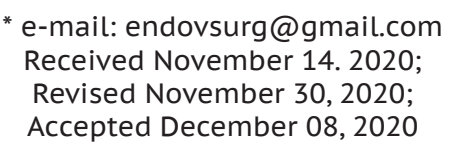

In this study, the authors attempted to systematize current information based on recommendations, large studies and meta-analyzes of the treatment of myocardial infarction in the elderly. Cardiovascular heart disease represents the leading cause of death in people aged 65 years and over. Acute myocardial infarction is one of the most socially important diseases with a high rate of mortality and disability. In elderly and old patients atypical forms of myocardial infarction are common. High rate of comorbidities, functional and socioeconomic status, side effects associated with drug administration create difficulty in the diagnosis and selection of treatment in the elderly. These patients need a prolonged monitoring with using an additional examinations and dynamic observation. Compared to younger subjects, elderly patients with acute myocardial infarction are less likely to receive evidence-based treatment, including myocardial revascularization therapy. Endovascular revascularization is currently the main standard for the treatment of acute myocardial infarction, but the advantage of the use of interventional cardiology techniques in elderly patients has been insufficiently studied. Older patients are generally underrepresented in cardiovascular trials. Modern scientific literature, illuminating issues of application of pharmacological and endovascular treatment of acute myocardial infarction in elderly and old age patients, contains fragmented and, in some cases, contradictory data, which forces researchers to continue studying new and promising methods of diagnosis and treatment of myocardial infarction in the elderly.

KEYWORDS: myocardial infarction; acute coronary syndrome; unstable angina; percutaneous coronary intervention; the elderly

\footnotetext{
ABBREVIATIONS:

AMI - acute myocardial infarction;

CABG - coronary artery bypass grafting;

CHF - chronic heart failure;

LV - left ventricle;

PCI - percutaneous coronary intervention;

PPCI - primary percutaneous coronary intervention;

STEMI - myocardial infarction within ST segment elevation

NRMI - National Registry of Myocardial Infarction;

GRACE - Global Registry of Acute Coronary Events;

TIME - Randomized Trial of Invasive Versus Medical Therapy in Elderly Patients;

STREAM - Strategic Reperfusion Early After Myocardial Infarction;

MI - myocardial infarction;

ACUITY - Acute Catheterization and Urgent Intervention Triage strateg Y;

NYHA III-IV FC - New York Heart Association III-IV Functional Class.
} 


\section{INTRODUCTION}

According to statistics, every year about one million people die from cardio-vascular disease in the Russian Federation [1]. It is known that ischemic heart disease plays the main role and causes $85 \%$ of death among all cardio-vascular diseases in elderly and old group of patients. Elderly age of patients with acute myocardial infarction (AMI) is associated with higher rate of mortality during hospitalization and in a long-term period [2]. Today enlargement trend in number of elderly and old patients with ischemic heart disease is noticed. It puts a priority on the prevention of age-related diseases and health conditions of the elderly population [3].

\section{SEARCH STRATEGY}

For this review, data were identified by searches of PubMed between January 1, 1996 and October 1, 2020 using the following terms: "myocardial infarction", "acute coronary syndrome", "unstable angina", "percutaneous coronary intervention" and "the elderly". Both full-text papers and abstracts were reviewed. Additional papers were identified from personal libraries and the reference lists of retrieved articles.

\section{Features of AMI in elderly}

During involution, a number of changes in human organism are taking place. Adaptation reserves go less: a response on pathogenic factors goes down, immune system decreases, a frequency of addition pathology and its condition increases, metabolism of drugs changes [4]. Unstable angina and AMI in elderly and old patients often goes atypically and characterizes several features. Description of symptoms differs from the classical one of substernal pressure with exertion. A character or location of pain may be different in elderly patients and sometimes present as an upper abdomen pain. Most elderly patients with AMI have arrhythmias or conduction disorders but only of minority of these are of clinical significance. Left bundle-branch block occurred in $5 \%$ of those $<65$ years but $33.8 \%$ of those $\geq 85$ years of age. The incidence of painless AMI increases with age, which leads to increased delays to hospitalization. In the NRMI registry (The National Registry of Myocardial Infarction) chest pain at presentation occurred in $89.9 \%$ of ST elevation myocardial infarction (STEMI) patients $<65$ years versus $56.8 \%$ of those $\geq 85$ years of age. The common occurrence of heart failure and atypical symptoms in older patients may divert diagnostic suspicion away from an acute ischemic event. Accordingly, a diagnosis of "other" (as opposed to unstable angina, rule-out AMI, or AMI) was more often recorded at admission in older adults ( $5 \%$ of those $<65$ versus $24 \%$ of those $\geq 85$ years of age) [5].

Elderly patients have more extensive coronary artery disease and more comorbidity. Higher atherosclerosis degree and longer ischemic heart disease widely exist in elderly patients, accompanied by collateral vessels formation [6]. Due to collateral vessels, acute occlusion of one artery does not cause a cardiogenic shock, while in young people occlusion of coronary artery often causes a large ischemic zone, acute myocardial dysfunction, acute cardiac insufficiency and cardiogenic shock [7]. In this situation, late reperfusion therapy may lead to aneurism and more over - may lead to myocardial rupture due to reperfusion damage [8]. However, according to the NRMI registry, acute heart failure as evidenced by Killip class $\geq 2$ at presentation occurred in $11.7 \%$ of STEMI patients $<65$ years versus nearly half ( $44.6 \%$ ) of those $\geq 85$ years of age. This can be explained by the fact that elderly patients in this study at baseline had a worse myocardial contractile function due to prior myocardial infarction and therefore, a greater risk of developing heart failure. Among STEMI patients in the NRMI registry, ST-segment elevation was present on the electrocardiogram of $96.3 \%$ of patients $<65$ years but only $69.9 \%$ of those $\geq 85$ years of age. In the SHOCK Trial Registry, shock occurs in $>10 \%$ of AMI patients $\geq 75$ years and is known to be due to advanced ventricular dysfunction or to ventricular muscle rupture [9].

Mortality rate in STEMI patients increase with age. In the GUSTO-I trial, the 30-day mortality rate increased from $3.0 \%$ among those $<65$ years to $30.3 \%$ among patients $\geq 85$ years [10].

In elderly and old patients a frequency and duration of diabetes mellitus is also bigger [11]. With the passage of time, it leads to micro- and macroangiopathy, which may become a reason of diffuse damage of coronary arteries and painless variant of AMI [12]. As a result - the fewer patients feel pain, the less they call emergency and get necessary help [2].

Because of the lower intensity of clinical manifestations of AMI, old people have longer latency to necessary treatment. In the Vital Heart Response registry [13] time from symptoms to first medical contact were longer for $\geq 75$ years vs those $<75$ years (median, 93 vs $78 \mathrm{~min} \mathrm{p}=0.008$ ) as well as time to PPCI (median, 166 vs 136 min p<0.001).

Strategy of treatment of AMI in elderly and reperfusion therapy

Most patients with AMI are admitted to coronary care units. The aims of the coronary care units are to reduce mortality, relieve symptoms, rapid treatment of complications and to minimize cardiovascular disability in the survivors. The main strategy of treatment of AMI is reperfusion therapy that is associated with lower risk of death and disability. Recent guidelines suggest that patients with AMI should undergo reperfusion therapy as soon as possible.

Elderly people have good results of reperfusion therapy. In the Vital Heart Response registry in those $\geq 75$ years outcomes by reperfusion ( $\mathrm{PCl}$, fibrinolysis and none) were: in-hospital death $13.3 \%, 9.4 \%$ and $19.7 \%$ ( $p=0.018)$, and composite of death, recurrent-AMI, cardiogenic shock and congestive heart failure $28 \%, 20 \%$ and $33.2 \%(p=0.022)$.

Elderly patients with STEMI more often have relative and absolute contraindications to reperfusion, so eligibility for reperfusion declines with age, and yet elderly patients are less likely to receive reperfusion even if eligible.

Timely reperfusion therapy improves outcomes in patients with STEMI. But it is known that elderly patients are less likely to receive reperfusion. In the GRACE registry, 30\% of elderly patients with STEMI presenting within 12 hours of symptoms did not receive therapy due to comorbidity compared to $13 \%$ of the younger patients.

Common reasons for excluding the elderly from reperfusion are their delayed presentation ( $>6$ hours from symptom onset) and electrocardiographic changes that are abnormal at baseline or of unclear duration [14]. In addition, many elderly patients present without ongoing chest pain and up to $9 \%$ have absolute contraindications 
to fibrinolytic therapy [15]. Relative contraindications, like poorly controlled hypertension, prior stroke, dementia, and chronic anticoagulation (eg, warfarin) are even more common than absolute contraindications in the elderly [16].

Interventional methods in treatment of AMI in elderly

The main strategy in treating people with AMI is effective revascularization, using pharmacology method or interventional procedures. For the last 10 years percutaneous coronary interventions $(\mathrm{PCl})$ and stenting of infarct-associated artery became the main standard methods in treating patients with AMI or unstable angina. Numerous of research tells us that introducing interventional methods significantly decreases the rate of mortality and increases quality of life parameters [17]. Elderly patients become candidates for revascularization in the majority of cases [1]. In the field of gerontology, it is interesting to determine, that there is much more good results of revascularizations among elderly patients, than among younger person [2]. In TIME research study it was shown that during revascularization the absolute risk of bleeding in elderly patients was paradoxically less, than in younger ones [18]. Moreover, the rate of mortality in the first 6 month after revascularization in the elderly was much miner, than in patients under 70 years old, said in research Rana O. and co. (7.0\% against $1.8 \%$ consequently) [19].

Together with technology development and increased accessibility in terms of modern medicine - the efficacy of treatment patients with AMI also grows. The results of meta-analyses De Luka L. and co. tell us, that during the last 10 years a number of $\mathrm{PCl}$ and frequency of medical prescription has increased.

During the period of treatment a rate of mortality in the first 30 days decreased from $14.6 \%(95 \% \mathrm{Cl} 9.9-20.4)$ to $9.5 \%$ (95\% Cl 7.7-11.6). Using of interventional cardiology in patients with AMI for the last 10 years significantly increased - from $26.6 \%$ to $68.4 \%$ ( $p<0.0001)$; a frequency of revascularization for this period raised from $9.9 \%$ to $51.7 \%$ ( $p<0.0001$ ). In this research $39.6 \%$ were older than 75 years [20].

\section{Fibrinolytic therapy}

Thrombolysis as well as primary angioplasty are recommended as reperfusion strategy for elderly patients presenting with AMI. Fibrinolytic therapy may be beneficial and lead to reduced morbidity and mortality if used carefully in selected elderly patients.

Data from the Fibrinolytic Therapy Trialists' Collaborative Group show that thrombolytic therapy significantly reduces mortality by $15 \%$ (from $29.4 \%$ with control treatment to $26.0 \%, p=0.03$ ) in patients over 75 years of age presenting within $12 \mathrm{~h}$ of symptom onset, with ST-segment elevation or bundle branch block [21]. However, in the 5788 patients $\geq 75$ years of age presenting with any electrocardiographic changes within $24 \mathrm{~h}$ of symptom onset, thrombolytic therapy reduced mortality nonsignificantly from $25.3 \%$ to $24.3 \%$ ( $95 \%$ confidence interval -16 to 36 ).

In the Vital Heart Response registry for those receiving no reperfusion therapy the composite event occurred in $33 \%$ in the elderly compared to $17 \%$ of the younger. With $\mathrm{PPCl}$ and fibrinolysis, it was $28 \%$ and $20 \%$ in the elderly and $16 \%$ and $10 \%$ in the younger, respectively. This was similarly shown when observing in-hospital death rates in the elderly with: no reperfusion therapy $20 \%, \mathrm{PPCl} 13 \%$ and fibrinolytic $9 \%$ and in the younger patients no reperfusion therapy $6.5 \%$, PPCI $4.6 \%$ and fibrinolytic $2.2 \%$. But these rates differ from previously published registry data analysis by Thiemann, et al. [22] who found that the 30-day crude mortality rates in elderly who received fibrinolytic were $18 \%$ compared to $15.4 \%$ for no reperfusion therapy. As studied in the Strategic Reperfusion Early After Myocardial Infarction study (STREAM), safety of the fibrinolysis in the elderly may be improved further with incorporation of the half dose fibrinolytic strategy in patients $>75$ years.

Despite evidence from several randomized trials that thrombolytic therapy has clear net benefits and is a costeffective treatment in the elderly, older age is associated with higher risk of complications, especially when it is performed with long time delay (more than 6 hours on a development of AMI symptoms). AMI patients older than 75 years treated with thrombolytics have an increased risk of intracerebral hemorrhage of approximately $1.4 \%$. The risk of fatal cardiac rupture gets higher in patients older than 70 years, receiving thrombolytic treatment with an incidence of 0.5 to $2 \%$ [23]. In the PRIMM75 study, thrombolysis in $>75$ years AMI patients was demonstrated as the strongest predictor of free wall rupture with a three-fold increase compared with those who did not receive reperfusion therapy [24].

\section{Pharmacological therapy of AMI in elderly}

There is no doubt that adequate and comprehensive pharmacological therapy in patients with $A M I$ is also very important. Drugs treatment aims at: pain relief, most often attempted using opiates (morphine), pharmacological coronary artery reperfusion (thrombolytic therapy), prevention of acute thrombosis in coronary arteries during $\mathrm{PCl}$ and early postoperative period (IIb-IIla glycoprotein receptor blockers, bivalirudin, unfractionated heparin); drugs-accessed vasodilatation (prolonged and shorteffective nitroglycerine, calcium antagonists); prevention of myocardial and vessels remodeling (angiotensin converting enzyme inhibitors), reduction of the necessary oxygen in myocardial tissue (beta-blockers), stabilization of atheromas (statins). In special cases, when complications take place, it may be necessary to use drugs for stimulating contraction (phenylephrine, dopamine); correction of bradycardia (atropine); antiarrhythmic drugs (amiodarone, lidocaine).

Evidence for adjunctive treatments such as lipidlowering agents, $\beta$-blockers, angiotensin-converting enzyme (ACE) inhibitors, and nitrates in elderly postmyocardial infarction (MI) patients are discussed. It has been proved that intravenous nitrates may reduce early and late mortality rates in elderly patients with AMI. It has been shown that beta blockers also help to elderly patients' survival. Recent large study confirm that the use of combined oral and intravenous atenolol in elderly patients can reduce vascular mortality by $23 \%$ after AMI. Thrombolytic therapy can improve left ventricular function and reduce mortality in AMI. Recent studies have confirmed significant benefits in terms of reductions early and late vascular mortality in elderly patients after thrombolysis [25]. In addition, thrombolytic therapy can produce a satisfactory coronary artery patency rate with an acceptable degree of safety up to 80 years of age.

Aspirin is still the most widely used and convenient antiplatelet agent. Therapy with aspirin has been shown to significantly reduce mortality, recurrent-AMI and stroke after AMI in elderly patients [25]. The use of aspirin is associated with $22 \%$ lower odds of 30 -day mortality in elderly AMI patients. 
It has been shown that unfractionated heparin reduce the incidence of left ventricular mural thrombus and early mortality in AMI patients.

For patients $\geq 75$ years with AMI the loading dose of clopidogrel and the intravenous enoxaparin can be omitted due to high risk of bleeding complications and the subcutaneous dose of enoxaparin can be reduced from 1 to $0.75 \mathrm{mg} / \mathrm{kg}$.

It is known that elderly patients get less medicines than younger ones because of poorer tolerability of drugs, a high degree of accumulation in the kidney and liver pathology, contraindications and lower adherence to treatment: betablockers are delivered in $55.9 \%$ against $71.2 \%(p<0.001)$, statins - $44.3 \%$ against $62.3 \%$ respectively $(p<0.001)$ [6]. Despite this, the frequency of the appointment of recommended drugs in the elderly has increased in recent years. Thus, early administration of beta-blockers by hospitalization, as well as using statins and dual antithrombotic therapy since 2001 to 2010, have significantly increased in this group of patients $(p<0.0001)[20]$.

\section{Drugs side effects in elderly patients with AM}

Elderly people have an increased risk of drugs side effects. Particularly it is associated with high risk of bleeding in terms of using dual antiplatelet therapy and anticoagulants, as well as in case of hypotension, bradycardia and renal failure. Besides the high risk of bleeding, which often takes place in elderly patients, the medium dosage of antithrombotic medicines may be too high [26]. The bleeding rates are higher in the elderly with major bleeding occurring in $13 \%$ vs $7 \%$ in the younger patients with STEMI. The rates of hemorrhagic stroke in the elderly are low and does not differ significantly between the elderly and younger patients (4 (0.6\%) vs 13 $(0.4 \%) \mathrm{p}=0.52)$. Although, ischemic stroke occurred more frequently in the elderly ( $8(1.2 \%)$ vs 7 (0.2\%), $p=0.002)$. In case of using unfractionated heparin, enoxaparin, IIb/IIla glycoprotein and $\mathrm{P}_{2} \mathrm{Y}_{12}$ receptor blockers in elderly, the risk of major bleeding also increases. Besides that, the risk of major bleeding is getting higher while a number of antithrombotic agents increases, including anticoagulants, aspirin, $\mathrm{P}_{2} \mathrm{Y}_{12}$ blockers and especially GP IIb/IIla blockers, as well as using femoral approach instead of radial approach during angiography and $\mathrm{PCl}$ [27]. A frequency of major bleeding complications is also bigger in case of using too high dosage of drugs. We can widely see it in patients with a high risk of hemorrhage side effects, particularly in women, elderly and patients with chronic kidney disease [26]. Using novel antithrombotic drugs during PCI makes it possible to reduce the risk of bleeding side-effects. Thus, according to ACUITY study, using Bivalirudin compared with combination of unfractionated heparin and GP IIb/IIla blockers significantly reduced a risk of major bleeding $(6.2 \%$ against $9.8 \%$ accordingly; $p=0.008$ ) [28].

Contrast-inducted nephropathy is one of the most dangerous side effect after $\mathrm{PCl}$ in patients with chronical kidney disease. In Kim, et al. [29] trial was shown that contrast-induced nephropathy was associated significantly with high mortality rate during hospitalization (18.2\% against $3.7 \%, p=0.001$ ) [30]. It is also important that the age of patients was not a factor of high risk of contrast-induced nephropathy. It means that it is necessary to be very careful when using high dosage of contrast during $\mathrm{PCl}$ (usually 3-4 $\mathrm{ml}$ per $1 \mathrm{~kg}$ of body weight) to prevent a toxic side effect on kidney.
Myocardial revascularization as a treatment for CHF in the outcome of $\mathrm{MI}$ in the elderly

Ischemic heart disease is the cause of systolic chronic heart failure (CHF) in two thirds of cases, often combined with diabetes mellitus and arterial hypertension. According to the Russian epidemiological studies, the prevalence of $\mathrm{CHF}$ in the general population is $7 \%$ (including clinically pronounced $-4.5 \%$ ), increasing from $0.3 \%$ in the age group from 20 to 29 years to $70 \%$ in people over 90 years old [31].

The main goals in treating of the elderly patients with chronic heart failure are to eliminate symptoms of CHF (shortness of breath, edema, etc.), to reduce the number of hospitalizations and to improve prognosis. At the same time, a decrease in mortality and the number of hospitalizations are the main criteria for the effectiveness of therapeutic measures. As a rule, this is accompanied with a reversal LV remodeling and a decrease of natriuretic peptides concentration [32]. Among all non-drug methods in $\mathrm{CHF}$ treatment, the most common one is myocardial revascularization (stenting of the coronary arteries or CABG - coronary artery bypass grafting). Revascularization of the myocardium in patients with $\mathrm{CHF}$ is recommended while angina attacs resistant to antianginal therapy are maintaining [33]. CABG surgery is recommended as the method of choice in patients with CHF with multivessel coronary artery disease with acceptable surgical risk. At the same time, an important condition for performing revascularization is the presence of a viable myocardium. Therefore, the evaluation of patients with heart failure should include an assessment of its viability. During CABG, it is possible to perform aneurysmectomy and plasty of the left ventricle in patients with severe CHF (NYHA III-IV FC), in the presence of a large aneurysm or a large thrombus in its cavity [34]

\section{DISCUSSION}

The age is a well-established risk factor for coronary artery disease and AMI [35]. Treatment tactics in older patients can be challenging for clinicians due to increased risk of adverse events with an increase of the age [36]. Older age was found to be a predictor of less use of an invasive approach in the treatment of AMI [37]. At the same time, in-hospital mortality after $\mathrm{PCl}$ decreased for all age groups over the past few years with the largest absolute reductions in patients $\geq 80$ years of age [38]. The proportion of elderly patients among patients referred for $\mathrm{PCl}$ continues to increase. At the same time, despite the increase in proportion of elderly people with more complex lesions who underwent $\mathrm{PCl}$, there is a decrease in the incidence of serious cardiovascular and cerebrovascular events over 10 years from $1 \%$ to $0.4 \%$ [39]. According to research results, although age is an important risk factor, older patients with AMI may benefit similarly or more from early invasive procedures [40].

In view of the increase in life expectancy and the rising topicality of active aging, there is a need to increase the proportion of older people in clinical trials, since they have higher rates of cardiovascular disease. At the same time, chronological age does not always adequately reflect the state of the body. Using the concept of biological age can potentially lead to more meaningful results. Certainly, one needs to consider other factors, such as frailty, cognitive impairment, risk of bleeding, and other concomitant medical conditions, that all can affect the decisions for 
revascularization in this age group. Our review of the current literature demonstrates that age by itself should not preclude elderly patients from revascularization [41].

\section{CONCLUSIONS}

Multiple studies have shown that the use of invasive cardiac procedures offered to older patients decreases as the patients grow older because of higher-risk features, such as heart failure, diabetes mellitus, and higher GRACE scores in the elderly patients. The use of $\mathrm{PCl}$ in the elderly is inadequate despite the fact that elderly patients may have higher benefit after $\mathrm{PCl}$ in $\mathrm{AMI}$ compared with younger age groups [37]. An early invasive approach is a safe treatment strategy for most elderly patients with AMI and has been shown to reduce mortality significantly. Our review of the literature suggests that there are robust evidence-based guidelines recommending $\mathrm{PCl}$ in higher-risk patients, such as elderly patients presenting with AMI; however, it remains underused in this population.

Although mortality rates from cardiovascular disease have declined significantly over the past two decades, the rate of decline has been much smaller for older patients compared with younger ones [42]. Therefore, clinicians should consider expanding the indication for invasive AMI treatments in the elderly.

\section{REFERENCES}

1. Kozlov K, Shanin V. Ischemic heart disease. SaintPetersburg: JeLBI-SPb; 2015.

2. Bogachev A, Kozlov K, Oleksyuk I. Coronary revascularization versus optimal medical therapy in elderly patients with stable angina. Advances in Gerontology. 2012; 2 (3): 261-7. PMID: 22550874.

3. Robinson M. Global health and global aging. San Francisco: Jossey-Bass; 2007. ISBN: 978-0-470-17583-5.

4. Tavrovskaja T, Kachesova A, Sokolova O. Myocardial infarction: thrombolysis, hospital mortality, myocardia rupture. Journal of arrhythmology. 2008; 51: 28-35.

5. Alexander K, Newby L, Armstrong P. ST-SegmentElevation Myocardial Infarction: A Scientific Statement for Healthcare Professionals From the American Heart Association Council on Clinical Cardiology: In Collaboration With the Society of Geriatric Cardiology. Circulation. 2007; (115): 2570-89. DOI: 10.1161/CIRCULATIONAHA.107.182616.

6. Fernández-Bergés D, Félix-Redondo F, ConsuegraSánchez L, et al. Infarto de miocardio en mayores de 75 años: una población en aumento. Estudio CASTUO. Revista Clínica Española. 2015;215(4):195-203. DOI:10.1016/j.rceng.2014.11.001.

7. Deok M, Eun-Ho L, Hyun J, et al. Does remote ischaemic preconditioning with postconditioning improve clinical outcomes of patients undergoing cardiac surgery? Remote Ischaemic Preconditioning with Postconditioning Outcome Trial. Eur. Heart J. 2014; 35 (3): 176-83. DOI: 10.1093/eurheartj/eht346.
The balance between the prevention of ischemic complications and haemorrhagic risks poses a difficult task for the doctor and requires an assessment of frailty and cognitive impairment, comorbidities, and treatment goals for each individual patient [36]. In the elderly population, frailty shares many risk factors with $\mathrm{AMI}$, both contributing to decrease in the physiologic reserve, leading to increased vulnerability. Studies have demonstrated that although $\mathrm{PCl}$ is underused in frail older patients, they are still likely to derive a significant survival benefit and improved quality of life after $\mathrm{PCl}$. Although there are risk stratification scores, such as the Essential Frailty Toolset and the Clinical Frailty score, there remains a need for comprehensive geriatric assessment to be incorporated in classic risk scores, such as GRACE. Presence of concomitant comorbidities, such as severe AS and/or atrial fibrillation with the need of long-term anticoagulation, poses challenges in choosing the best revascularization strategy in older patients. Therefore, there is a strong need for greater inclusion and better representation of elderly patients in revascularization clinical trials and expanded registries to monitor the benefits and risks of different revascularization strategies in older adults to inform the best practice for this growing age group [41].

8. Dubey L. A rare case of stenting of spontaneous dissection of Shepherd's Crook right coronary artery. ARYA Atheroscler. 2014; 10 (2): 129-32. PMID: 25161681; PMCID: PMC4144368.

9. Thompson CR, Buller CE, Sleeper LA, et al. Cardiogenic shock due to acute severe mitral regurgitation complicating acute myocardial infarction: a report from the SHOCK Trial Registry: Should we use emergently revascularize Occluded Coronaries in cardiogenic shock? J. Am. Coll. Cardiol. 2000; 36 (suppl A): 1104-9. DOI: 10.1016/s0735-1097(0o)00846-9.

10. White HD, Barbash GI, Califf RM, et al. Age and outcome with contemporary thrombolytic therapy: results from the GUSTO-I trial: Global Utilization of Streptokinase and TPA for Occluded Coronary Arteries Trial. Circulation. 1996; 94: 1826-33. DOI: 10.1161/01.cir.94.8.1826.

11. Kirkman M, Briscoe V, Clark N, et al. Diabetes in Older Adults. Diabetes Care. 2012; 35 (12): 2650-64. DOI: 10.2337/dc121801.

12. Chiariello $M$, Indolfi C. Silent Myocardial Ischemia in Patients with Diabetes Mellitus. Circulation. 1996; 93 (12): 208991. DOI: 10.1161/01.CIR.93.12.2089.

13. Toleva O, Ibrahim Q, Brass N, et al. Treatment choices in elderly patients with ST: elevation myocardial infarctioninsights from the Vital Heart Response registry. Open Heart. 2015; 2 (1): e000235. DOI: 10.1136/ openhrt-2014-000235.

14. Krumholz HM, Friesinger GC, Cook EF, et al. Relationship of age with eligibility for thrombolytic therapy and mortality 
among patients with suspected acute myocardial infarction. J. Am. Geriatr. Soc. 1994; 42: 127-31. DOI: 10.1111/j.1532-5415.1994. tbo4938.x.

15. Krumholz HM, Gross CP, Peterson ED, et al. Is there evidence of implicit exclusion criteria for elderly subjects in randomized trials? Evidence from the GUSTO-1Study. Am. Heart J. 2003; 146 (5): 839-47. DOI: 10.1016/S0002-8703(03)00408-3.

16. Antman EM, Anbe DT, Armstrong PW, et al. ACC/AHA guidelines for the management of patients with ST-elevation myocardial infarction: executive summary: a report of the ACC/ AHA Task Force on Practice Guidelines (Committee to Revise the 1999 Guidelines for the Management of Patients With Acute Myocardial Infarction). J. Am. Coll. Cardiol. 2004; 44 (3): 671-719. DOI: 10.1161/01.CIR.0000134791.68010.FA.

17. Anisimov V, Baranov V, Khavinson V. Programme "Prevention of Age-Related Pathology and Accelerated Aging, Reducing Premature Mortality and the Extension of the Working Life Span of the Population": guidelines. Saint Petersburg: IPK KOSTA; 2008.

18. Pfisterer M. Long-Term Outcome in Elderly Patients with Chronic Angina Managed Invasively Versus by Optimized Medical Therapy: Four-Year Follow-Up of the Randomized Trial of Invasive Versus Medical Therapy in Elderly Patients (TIME). Circulation. 2004; 110 (10): 1213-8. DOI: 10.1161/01. CIR.0000140983.69571.BA.

19. Rana O. Percutaneous coronary intervention in the very elderly ( $\geq 85$ years): trends and outcomes. Br. J. Cardiol. 2013; 20: 27-31. DOI:10.5837/bjc.2013.006.

20. De Luca L, Olivari Z, Bolognese L, et al. A decade of changes in clinical characteristics and management of elderly patients with non-ST elevation myocardial infarction admitted in Italian cardiac care units. Open Heart. 2014; 1 (1): 148. DOI: 10.1136/openhrt-2014-000148.

21. White H. Debate: Should the elderly receive thrombolytic therapy or primary angioplasty? Trials. 2000; 1 : 150-4. DOI: 10.1186/cvm-1-3-150.

22. Thiemann DR, Coresh J, Schulman SP, et al. Lack of benefit for intravenous thrombolysis in patients with myocardial infarction who are older than 75 years. Circulation. 2000; 101 (19): 2239-46. DOI: 10.1161/01.CIR.101.19.2239.

23. Becker RC, Hochman JS, Cannon CP, et al. Fatal cardiac rupture among patients treated with thrombolytic agents and adjunctive thrombin antagonists: observations from the Thrombolysis and Thrombin Inhibition in Myocardial Infarction 9 Study. J. Am. Coll. Cardiol. 1999; 33 (2): 479-87. DOI: 10.1016/ s0735-1097(98)00582-8.

24. Bueno $\mathrm{H}$, Martínez-Sellés $\mathrm{M}$, Pérez-David $\mathrm{E}$, et al. Effect of thrombolytic therapy on the risk of cardiac rupture and mortality in older patients with first acute myocardial infarction. Eur. Heart J. 2005; 26 (17): 1705-11. DOI: 10.1093/ eurheartj/ehi284.

25. ISIS-2. Randomised trial of intravenous streptokinase, oral aspirin, both of neither among 17187 cases of suspected acute myocardial infarction. Lancet. 1988; 2 (8607): 349-60. PMID: 2899772

26. Alexander K. Excess Dosing of Antiplatelet and Antithrombin Agents in the Treatment of Non-ST-Segment Elevation Acute Coronary Syndromes. JAMA. 2005; 294 (24): 3108. DOI:10.1001/jama.294.24.3108.

27. Zhen-xian $Y$, Yu-jie Z, Ying-xin Z, et al. Safety and feasibility of transradial approach for primary percutaneous coronary intervention in elderly patients with acute myocardial infarction. Chinese medical journal. 2008; 121 (9): 782-6. DOI: 10.1097/00029330-200805010-00004.

28. Mehran R, Nikolsky E, Lansky A, et al. Impact of Chronic Kidney Disease on Early (30-Day) and Late (1-Year) Outcomes of Patients with Acute Coronary Syndromes Treated with Alternative Antithrombotic Treatment Strategies. JACC: Cardiovascular Interventions. 2009; 2 (8): 748-57. DOI: 10.1016/j. jcin.2009.05. 018.

29. Kozlov K, Semigolovskij N, Shnejder J. Angiography, angioplasty and stenting of the coronary arteries in the diagnosis and treatment of coronary heart disease. Guidelines. Saint-Petersburg: JeLBI-SPb; 2001.

30. Kim J, Yang J, Choi S, et al. Predictors of Outcomes of Contrast-Induced Acute Kidney Injury After Percutaneous Coronary Intervention in Patients With Chronic Kidney Disease. The American Journal of Cardiology. 2014; 114 (12): 1830-5. DOI: 10.1016/j.amjcard. 2014.09.022.

31. Ageev FT, Belenkov YuN, Fomin IV, et al. Prevalence of chronic heart failure in the European part of the Russian Federation - data from EPOCH - CHF. Journal of Heart Failure. 2006; 7 (1): 112-5. DOI: $10.18087 /$ cardio. 2475

32. Khubulava GG, Kozlov KL, Bogomolov AN, et al. Auxiliary devices in the treatment of chronic heart failure in elderly and senile patients. Pharmacy Formulas. 2020; 2 (3): 4057. DOI: 10.17816/phf41944/2713-153X-2020-3-2-40-57.

33. Pursnani S, Korley F, Gopaul R, et al. Percutaneous coronary intervention versus optimal medical therapy in stable coronary artery disease: a systematic review and meta-analysis of randomized clinical trials. Circ. Cardiovasc. Interv. 2012; 5 (4): 476-90. DOI: 10.1161/CIRCINTERVENTIONS.112.970954.

34. Dor V, Civaia F, Alexandrescu C, et al. Favorable effects of left ventricular reconstruction in patients excluded from the Surgical Treatments for Ischemic Heart Failure (STICH) trial. J. Thorac. Cardiovasc. Surg. 2011; 141 (4): 905-16. DOI: 10.1016/j. jtcvs.2010.10.026.

35. Kung H-C, Hoyert DL, Xu J, et al. Deaths: final data for 2005. Natl Vital Stat Rep. 2008; 56 (10): 1-120. PMID: 18512336.

36. Engberding N, Wenger NK. Acute Coronary Syndromes in the Elderly. F1000 Research. 2017; 6: 1791. DOI: 10.12688/ f100oresearch.11064.1.

37. Alexander KP, Newby LK, Armstrong PW, et al. Acute coronary care in the elderly, part II: ST-segment-elevation myocardial infarction: a scientific statement for healthcare 
professionals from the American Heart Association Council on Clinical Cardiology: in collaboration with the Society of Geriatric Cardiology. Circulation. 2007; 115: 2570-89. DOI: 10.1093/eurheartj/ehlo67.

38. Singh M, Peterson ED, Roe MT, et al. Trends in the association between age and in-hospital mortality after percutaneous coronary intervention: National Cardiovascular Data Registry experience. Circ. Cardiovasc. Interv. 2009; 2: 206. DOI: 10.1161/CIRCINTERVENTIONS.108.826172.

39. Rajani R, Lindblom M, Dixon G, et al. Evolving trends in percutaneous coronary intervention. Br. J. Cardiol. 2011; 18: $73-6$.
40. Fox KA, Clayton TC, Damman P, et al. Long-term outcome of a routine versus selective invasive strategy in patients with non-ST-segment elevation acute coronary syndrome a meta-analysis of individual patient data. J. Am. Coll. Cardiol. 2010; 55: 2435-45. DOI: 10.1016/j.jacc. 2010.03.007.

41. Kumar S, McDaniel M, Samady H, et al. Contemporary Revascularization Dilemmas in Older Adults. Journal of the American Heart Association. 2020; 9 (3): e014477. DOI: 10.1161/ JAHA.119.014477.

42. Roger VL, Jacobsen SJ, Weston SA, et al. Trends in heart disease deaths in Olmsted County, Minnesota, 19791994. Mayo Clin Proc. 1999; 74 (7): 651-7. DOI: 10.4065/74.7.651.

\section{ADDITIONAL INFORMATION ABOUT AUTHORS}

Kirill L. Kozlov, Doctor of Medicine (MD), Professor, Deputy Director for Educational and Methodological Work, Saint Petersburg Institute of Bioregulation and Gerontology Research Center, Saint Petersburg, Russia; Professor of the 1st department (surgery for advanced medical doctors) named after P.A. Kupriyanov, S.M. Kirov Military Medical Academy, Saint Petersburg, Russia; e-mail:kozlov_kl@mail.ru

Andrey N. Bogomolov, Ph.D. in Medicine, Senior Researcher of the Laboratory of Age-Related Pathology of the Cardiovascular System of the Department of Clinical Gerontology and Geriatrics, Saint Petersburg Institute of Bioregulation and Gerontology Research Center, Saint Petersburg, Russia; Saint Petersburg, Russia; e-mail: endovsurg@gmail.com

Nikolay G. Lukianov, Ph.D. in Medicine, Associate Professor, Associate Professor of the 1st department (surgery for advanced medical doctors) named after P.A. Kupriyanov, S.M. Kirov Military Medical Academy, Saint Petersburg, Russia; e-mail: loncorio01@rambler.ru

Ekaterina I. Senkina, Researcher of the Laboratory of Age-Related Pathology of the Cardiovascular System, Saint Petersburg Institute of Bioregulation and Gerontology Research Center, Saint Petersburg, Russia; e-mail:5436588@gmail.com

Anastasia E. Pukhalskaya, Researcher of the Laboratory of Age-Related Pathology of the Cardiovascular System, Saint Petersburg Institute of Bioregulation and Gerontology Research Center, Saint Petersburg, Russia; e-mail: nastyapuh96@mail.ru

\section{ДОПОЛНИТЕЛЬНЫЕ СВЕДЕНИЯ ОБ АВТОРАХ}

Кирилл Ленарович Козлов, А-р мед. наук, профессор, заместитель директора по учебно-методической работе Санкт-Петербургского института биорегуляции и геронтологии, Санкт-Петербург, Россия; профессор 1-й кафедры и клиники хирургии усовершенствования врачей им. П.А. Куприянова Военно-медицинской академии им. С.М. Кирова Министерства обороны РФ, Санкт-Петербург, Россия; e-mail: kozlov_kl@mail.ru

Андрей Николаевич Богомолов, канд. мед. наук, старший научный сотрудник лаборатории возрастной патологии сердечно-сосудистой системы отдела клинической геронтологии и гериатрии Санкт-Петербургского института биорегуляции и геронтологии, Санкт-Петербург, Россия; e-mail: endovsurg@gmail.com

Екатерина Ивановна Сенькина, научный сотрудник лаборатории возрастной патологии сердечно-сосудистой системы отдела клинической геронтологии и гериатрии Санкт-Петербургского института биорегуляции и геронтологии, Санкт-Петербург, Россия; e-mail: 5436588@gmail.com

Николай Георгиевич Лукьянов, канд. мед. наук, доцент, доцент 1-й кафедры и клиники хирургии усовершенствования врачей им. П.А. Куприянова Военно-медицинской академии им. С.М. Кирова Министерства обороны РФ, Санкт-Петербург, Россия; e-mail: loncorio01@rambler.ru

Анастасия Эдуардовна Пухальская, научный сотрудник лаборатории возрастной патологии сердечно-сосудистой системы Санкт-Петербургского института биорегуляции и геронтологии, Санкт-Петербург, Россия; e-mail: nastyapuh96@mail.ru

The Authors declare that they have no conflicts of interest.

Funding: This research received no specific grant from any funding agency in the public, commercial, or not-for-profit sectors. 


\title{
Современные аспекты лечения инфаркта миокарда у пожилых пациентов
}

\author{
๑2020. К.Л. Козлов ${ }^{1,2}$, А.Н. Богомолов², Е.И. Сенькина ${ }^{1}$, Н.Г. Лукьянов², А.Э. Пухальская² \\ ${ }^{1}$ Военно-медицинская академия им. С.М. Кирова Министерства обороны РФ, Санкт-Петербург, Россия \\ ${ }^{2}$ Санкт-Петербургский институт биорегуляции и геронтологии, Санкт-Петербург, Россия \\ * e-mail: endovsurg@gmail.com \\ Поступила в редакцию 14.11.2020 г. \\ После доработки 30.11.2020 г. \\ Принята к публикации 08.12.2020 г.
}

В данном исследовании авторы предприняли попытку систематизировать текущую информацию на основе рекомендаций, крупных исследований и метаанализов лечения инфаркта миокарда у пожилых людей. Сердечно-сосудистые заболевания сердца представляют собой ведущую причину смерти людей старше 65 лет. Острый инфаркт миокарда - одно из наиболее социально значимых заболеваний с высоким уровнем смертности и инвалидности. У пациентов нередки атипичные формы инфаркта миокарда. Высокий уровень сопутствующих заболеваний, функциональный и социально-экономический статус, побочные эффекты, связанные с приемом лекарств, создают трудности в диагностике и выборе лечения у пожилых людей. Эти пациенты нуждаются в длительном наблюдении с использованием дополнительных обследований и динамического наблюдения. По сравнению с более молодыми пациентами пожилые пациенты с острым инфарктом миокарда с меньшей вероятностью получат научно обоснованное лечение, включая терапию реваскуляризации миокарда. Эндоваскулярная реваскуляризация в настоящее время является основным стандартом лечения острого инфаркта миокарда, но преимущества использования методов интервенционной кардиологии у пожилых пациентов изучены недостаточно. Пациенты старшего возраста обычно недостаточно представлены в сердечно-сосудистых исследованиях. Современная научная литература, освещающая вопросы применения фармакологического и эндоваскулярного лечения острого инфаркта миокарда у пациентов пожилого и старческого возраста, содержит разрозненные, а в некоторых случаях противоречивые данные, что заставляет исследователей продолжать изучение новых и перспективных методов диагностики и лечения инфаркта миокарда у пожилых людей.

КЛЮЧЕВЫЕ СЛОВА: инфаркт миокарда; острый коронарный синдром; нестабильная стенокардия; чрескожное коронарное вмешательство; пожилые люди 